\title{
127. 人工股関節撮影におけるコンピュータの技術支援について \\ A radiographic study on Computer assistid Technology in Total Hip Prosthesis
}

昭和大学病院 中央放射線部

○中澤 靖夫 伊藤 美香 岩井 譜憲 加藤 京一 新田 勝 神田 幸助

(Yasuo Nakazawa) (Mika Itoh) (Tsugunori Iwai) (Kyouichi Katoh) (Msaru Nitta) (Kousuke Kanda)

\section{【目的】}

社会の高齢化にとあなう高年歯者の関節疾患に対する人工関節置換術は年々増加の一途をたどり今

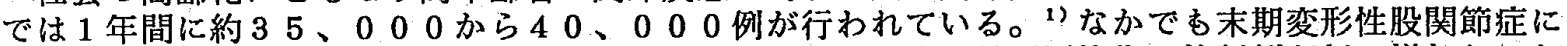
対する人工股関節全置換術や大腿骨頸部内側骨折に対する大腿骨頭置換術の施行例が年々増加してお り、そのフォローアップとX線写真の再現性は益々重要である。

そこで我々はフォローアップの重要性に着目し、X線写真の再現性向上を目的としてコンピュターを 用いてシステムの構築について検討したので報告する。

【方法】

1) 聅患別撮影法の範疇にはいる人工股関節撮影法の臨床的に要求されている読影ポイントについて 検討した。

2) 当院一般撮影部門に拈ける、93 年 8 月のロス率、ロス要因、について調查し、再撮影の原因に ついて検討した。

3）再現性向上のためにはどの様なシステムを組み立てたらいいのかを検討した。

【使用機器】
1) X 線撮影装置 : 島津製作所 X U D - 150
2) コンピューター：N E C
3) 画像ボード:カノープス C V I - 98 II
4) $8 \mathrm{~mm}$ ビデオ: S O N Y
P C $98001 \mathrm{E} \mathrm{X}$

【結果】

1) 読影上のチェックポイントについて検討した結果、次の 5 項目があげられる。

(1) stemの䯣腔適合性。

(2)micro-movementによる骨反応。

(3) stem周囲のradiopaquelineの目立ち。

(4) femoral neck $\omega$ rounded of $f$

(5)骨萎縮

2) 当院における再撮影の年間傾向はフレッシュマンの入社時期に合わせて多くなり、8月頃には年 間平均に落ちつく傾向にある。表 1 に 8 月のロス率を表した。

総ロス枚数の46.6\%が骨系のロスである。

その中の股関節ロス枚数は 10 枚であり、骨系全体の

2. $7 \%$ である。

8 月の総ロス枚数に対する原因別ロスの割合は
(1)濃度オーバー
( $20.4 \%)$
(2)濃度アンダー
( $14.4 \%)$
(3)体位不良
( $19.0 \%)$
(4)体位不良による欠像（9.1\%）
(5)その他

( $37.1 \%)$ である。

\begin{tabular}{|ccc|}
\hline 8月の総ロス枚数 & 789. & 枚 \\
ロス率 & $3.62 \%$ \\
その内骨系のロス枚数 & 368 & 枚 \\
骨系の中の & 10 & 枚 \\
股関のロス饰数 & 1 \\
\hline
\end{tabular}

3）再現性の向上について検討した結果、次ぎの事が考えられる。

(1)患者個々の撮影条件記録ノ一トを作り、撮影の度に過去の撮影条件を参考にする。

(2)撮影の度に、過去のX線写真情報を読んでから撮影する。

(3)同一撮影者が撮影する。

しかし、大病院のシステムでは以上の3 項目を実現する事は難しい状況にある。そこで我々はコンピ ュタ一支援によるシステム構築について検討した。その結果、次の構築目標を揭げてシステムの開発 に取り組んだ。

(1)再撮影の原因である写真濃度の過不足をなくす。 $\rightarrow$ 撮影条件の記憶、表示

(2)再撮影の原因である体位不良を無くす。画像の記憶、表示

(3)臨床に対応できるシステムの流れを作る。

【まとめ】

1）人工股関節・人工骨頭撮影における再現性の向上について、臨床上の読影のチェックポイントや 再撮影の原因分析をむとに新しいシステムの構筑を行った。

2) 市肘されているコンピュターシステムを組み合わせて、実際に動かす事ができた。

【文献】

1) 折茂 肇、林 泰史：老年者の救急処置とリハビリテーションの実際、3 $7-40$ 、

メジカルピュー社、( $\left(\begin{array}{llll}1 & 9 & 9 & 3\end{array}\right)$ 